\title{
Article \\ Investigation of the Mechanical Behavior of Polypropylene Fiber-Reinforced Red Clay
}

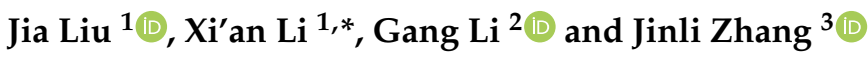 \\ 1 School of Geological Engineering and Geomatics, Chang'an University, Xi'an 710054, China; \\ 15929935077@163.com \\ 2 School of Civil Engineering, Xijing University, Xi'an 710123, China; T_bag945@126.com \\ 3 Institute of Geotechnical Engineering, Dalian University of Technology, Dalian 116024, China; \\ jlzhang@dlut.edu.cn \\ * Correspondence: dclixa@chd.edu.cn
}

check for updates

Citation: Liu, J.; Li, X.; Li, G.; Zhang, J. Investigation of the Mechanical Behavior of Polypropylene Fiber-Reinforced Red Clay. Appl. Sci. 2021, 11, 10521. https://doi.org/ 10.3390/app112210521

Academic Editors: Xiaowu Tang and Chao Xu

Received: 11 September 2021

Accepted: 4 November 2021

Published: 9 November 2021

Publisher's Note: MDPI stays neutral with regard to jurisdictional claims in published maps and institutional affiliations.

Copyright: (c) 2021 by the authors. Licensee MDPI, Basel, Switzerland. This article is an open access article distributed under the terms and conditions of the Creative Commons Attribution (CC BY) license (https:/ / creativecommons.org/licenses/by/ $4.0 /)$.

\begin{abstract}
Red clay is not easy to use as a natural foundation because of its high water content, high plasticity index, large void ratio, and susceptibility to shrinkage and cracking. In this study, consolidated undrained triaxial tests were conducted to examine the mechanical properties of polypropylene fiber-reinforced red clay and to analyze the influence of the fiber content $(F C)$, fiber length $(F L)$, and cell pressure on its shear strength. By performing a regression analysis on the test data, a hyperbolic constitutive model that considers the influence of $F C, F L$, and cell pressure was established, and a method was developed to estimate the parameters of the model. The findings show that, in contrast with the nonreinforced red clay, the fiber-reinforced red clay had a stress-strain curve characterized by typical strain hardening, with the shear strength increasing with FC, FL and cell pressure. The calculated results of the model coincide with the test results well, confirming that the hyperbolic model could appropriately describe the stress-strain relationship of polypropylene fiber-reinforced red clay and have reference value for the design and construction of fiber-reinforced red clay foundations.
\end{abstract}

Keywords: red clay; polypropylene fiber; fiber content; fiber length; hyperbolic model

\section{Introduction}

Rapid socioeconomic development, particularly accelerating industrialization and urbanization, is accompanied by the rapid emergence of massive urban buildings, high-speed railways, and freeways. Such development inevitably leads to the challenge of foundation engineering on unfavorable soils. Reinforcement techniques for soil are popular in geotechnical engineering. Geosynthetics (for instance, geogrids, geotextiles, geomembranes, and geocells) are widely utilized as reinforcement materials and have shown significant improvement effects in subgrade bed reinforcements, foundation base treatments, and applications to special-soil subgrades [1-5]. However, geosynthetics have vulnerabilities. In particular, when subjected to an external load, the reinforcement-filler interface may easily develop failure surfaces, thereby compromising the overall performance of the reinforced structure [6]. To effectively overcome this vulnerability of geosynthetics, researchers have attempted to use fibers to reinforce soils [7-10]. Fibers are mixed into soils at a certain ratio to create a composite material. The fiber is randomly and uniformly distributed in the soil to connect the fiber filaments and soil particles effectively. The fiber serves to confine the soil deformation in all directions, inhibit the development of failure surfaces, and thus enhance the shear strength through the fiber's tensile strength and its friction and interlocking effect on the soil particles. Studies have shown that fiber could reinforce the shear strength, tensile strength, and liquefaction resistance of soils, but the improvement effect is influenced by a multitude of factors, for instance, fiber type, content, and length as well as cell pressure and particle gradation [11-15]. 
Many kinds of fibers are used in the method of fiber reinforcement to improve soil properties, including artificial fibers and natural fibers. Commonly used artificial fibers are PVA, polypropylene, nylon, and carbon fiber. Rafalko et al. [16] demonstrated that the toughness and strength of fiber-reinforced clay increased due to the addition of longer fibers, and the performance of PVA fiber is better than that of inert fiber. Boz and Sezer [17] concluded that freeze-thaw cycles decreased the UCS and ultrasonic pulse velocity of fiber-reinforced clay and that the polypropylene fiber was more resistant to freeze-thaw action than basalt fiber. Tomar et al. [18] indicated that polypropylene fiber acts as a reinforcing material and limits the development of tension cracks through the bridge effect on fiber-reinforced clay soil. Estabragh et al. [19] concluded that the UCS and axial strain of clay were improved through the addition of nylon fiber, and the failure modes changed from brittle to ductile. Gao et al. [7] pointed out that the UCS and brittle failure of clay were significantly improved with the addition of carbon fiber, and the reinforcement mechanism was a single carbon fiber (one-dimensional effect) and a fiber network (three-dimensional effect), respectively. Common natural fibers include basalt, hair, and coir fibers. Gao et al. [20] concluded that the basalt fiber could obviously improve the unconfined compressive strength (UCS) of clay soil, and the optimum values of $F C$ and FL were $0.25 \%$ and $12 \mathrm{~mm}$, respectively. Basson and Ayothiraman [21] investigated the shrinkage cracking properties of fiber-reinforced clay soil and concluded that the geometric and morphic behaviors of crack shapes were obviously changed by fiber action, and the polypropylene fiber was more effective in preventing cracking than the human hair and coir fibers. Anggraini et al. [22] observed that the shear strength and durability of marine clay were improved by nanomodified coir fibers, and the tensile strength and friction between the interfaces were the primary mechanisms to control the reinforcing effect.

Many studies on the influence of $F L$ and $F C$ on the shear strength and tensile strength of reinforced soil have been carried out. Based on the reverse direct shear test, Mirzababaei et al. [8] indicated that the shear strength increased with an increase in $F C$ and $F L$, whereas the rate of increase decreased with the number of cycles. Ozkul and Baykal [9] concluded that the ductility, toughness, and resistance to tensile of clays improved with the addition of short fibers. Olgun [23] indicated that fiber addition results in the increased compressive and tensile strength of stabilized soil, and the shrinkage limit and crack reduction increased as FC and FL increased. Kravchenko et al. [24] demonstrated that the dynamic shear modulus of fiber-reinforced clay decreased as cell pressure increased, whereas the damping ratio increased with increasing shear strain and FC. Xue et al. [25] concluded that the cracking intensity factor of fiber-reinforced clay improved as FC increased, whereas the effect on surface contraction was non-significant. Meanwhile, the UCS and shear strength initially increased and then decreased as FC increased. Fiber-reinforced soil improves the strength of soil in a freeze-thaw cycle environment. Gao et al. [11] noted that the static and dynamic tensile strength of clay exposed to a freeze-thaw effect was obviously increased by the adjunction of basalt fiber, and the tensile strength did not continuously decrease with the freeze-thaw cycles.

Red clay-a high-plasticity clay formed by the strong chemical weathering of carbonate rocks, which are widely distributed in China (e.g., the Yunnan-Guizhou Plateau, eastern Sichuan, Hunan, Hubei, northern Guangdong, and northern Guangxi)—severely affects foundation stability because of its high water content, high plasticity index, large void ratio, and susceptibility of shrinkage and cracking. Thus, red clay foundations must be appropriately treated prior to the construction of superstructures. Jiang et al. [26] studied the mechanical characteristics of red clay reinforced by glass fiber with different contents by conducting unconfined compression tests and using the discrete element method. They concluded that the addition of glass fiber slowed the rapid development of cracks in the soil and increased the compressive strength of reinforced soil. With an increase in $F C$, the damage degree of the reinforced soil decreased, the susceptibility of the reinforced soil to local failures along the fiber-soil interface enlarged, and the compressive strength of the reinforced soil decreased. Dong et al. [27] reinforced red clay with different contents of lignin 
fiber and found that, with an increase in $F C$, the modulus of compression of reinforced red soil initially increased and then decreased, the internal friction angle $(\varphi)$ basically did not vary, and the cohesion (c) exhibited a decrease-increase-decrease variation pattern. Wan and Peng [28] found that the addition of certain amounts of glass fiber and lime into red clay resulted in a notable increase in the modulus of compression, and the addition of lime resulted in a larger increase in the modulus of compression than the addition of glass fiber. The modulus of compression of the fiber-reinforced soil initially increased and then decreased with increases in $F C$ and $F L$, peaking at an $F C$ of $1 \%$ and an $F L$ of $9 \mathrm{~mm}$. Zeng et al. [6] demonstrated that the unconfined compressive strength of a polypropylene fiber-reinforced soil increased as $F C$ and $F L$ increased and was 1.18 to 2.54 times that of plain soil. Fiber could ameliorate the residual strength and resistance to failure of red clay and alter the failure mode from brittle to plastic. This change occurs because the fiber forms a spatial network structure in the soil that serves to confine the deformation and improves the integrity of the soil.

Studies have clearly shown that fiber reinforcement could ameliorate the mechanical characteristics of soil, thus significantly improving the strength, stiffness, liquefaction resistance, and stability of the foundation. Existing studies on fiber-reinforced soils have mainly focused on sands, with few studies on clays, especially the shear strength of red clay. Therefore, this study investigated the mechanical properties of polypropylene fiberreinforced red clay and analyzed the effects of $F C, F L$, and cell pressure on the shear strength of the polypropylene fiber-reinforced red clay by triaxial tests. By fitting the test data, a hyperbolic constitutive model that considers the effects of $F C, F L$, and cell pressure was established. The model is of reference value in the design and construction of fiber-reinforced red clay foundations.

\section{Materials and Methods}

\subsection{Testing Materials}

The red clay sample was collected from Dalian, China. It was air dried, roller compacted, and screened with a $0.5 \mathrm{~mm}$ sieve for subsequent use. The main physical and mechanical characteristics of red clay are shown in Table 1. A single-strand polypropylene fiber with a circular cross-section and good dispersibility provided in the form of filament bunches was used in the tests. The physical and mechanical characteristics of the fiber are shown in Table 2. Fiber filaments of different lengths $(7,13$, and $19 \mathrm{~mm})$ were used in the study.

Table 1. Physical characteristics of red clay.

\begin{tabular}{cccccccc}
\hline Parameters & $w / \%$ & $w_{\mathrm{op}} / \%$ & $w_{\mathbf{P}} / \%$ & $w_{\mathrm{L}} / \%$ & $I_{\mathbf{P}}$ & $\rho /\left(\mathrm{g} / \mathrm{cm}^{3}\right)$ & $\rho_{\mathrm{dmax}} /\left(\mathrm{g} / \mathrm{cm}^{3}\right)$ \\
\hline Values & 8.5 & 16.8 & 17.1 & 33.4 & 16.3 & 1.65 & 1.83 \\
\hline
\end{tabular}

Table 2. Physical characteristics of polypropylene fiber.

\begin{tabular}{cc}
\hline Parameters & Values \\
\hline Linear density $/$ dtex & 7.33 \\
Diameter $d / \mathrm{mm}$ & 0.025 \\
Gravity $\gamma /\left(\mathrm{g} / \mathrm{cm}^{3}\right)$ & 0.91 \\
Tensile strength $/ \mathrm{MPa}$ & 592 \\
Elongation at break $/ \%$ & 26.4 \\
Initial elasticity modulus $/ \mathrm{MPa}$ & 4479 \\
Fusion point $/{ }^{\circ} \mathrm{C}$ & 163 \\
Ignition point $/{ }^{\circ} \mathrm{C}$ & 590 \\
Resistance of acidity and basicity & High \\
\hline
\end{tabular}




\subsection{Specimen Preparation}

The fiber filaments and red clay were uniformly and randomly mixed to ensure a good homogeneity of the prepared specimens. After numerous tests, it was found that when the clay had a high water content (close to the liquid limit), the fiber filaments could be basically uniformly distributed by adding the fiber filaments into the clay while stirring the fiber-clay mixture for a long time. However, obtaining the water content required for the specimens was difficult with this method. The issue of excessively high water content was resolved as follows: An appropriate amount of water was mixed with a mass of red clay to turn it into a flowing plastic material. The clay was loaded into a mixer, which was then started. Fiber filaments were added into the mixer while the fiber-clay mixture was stirred until the preset amount of fiber was mixed into the clay. The uniformity of the fiber-clay mixture was repeatedly checked while the mixture was being stirred. The uniformly mixed fiber-clay mixture was loaded into a container (Figure 1) and sealed by covering the surface with plastic cloth. The water in the specimens was drained using a vacuum pump until the water content was lowered to the required level.

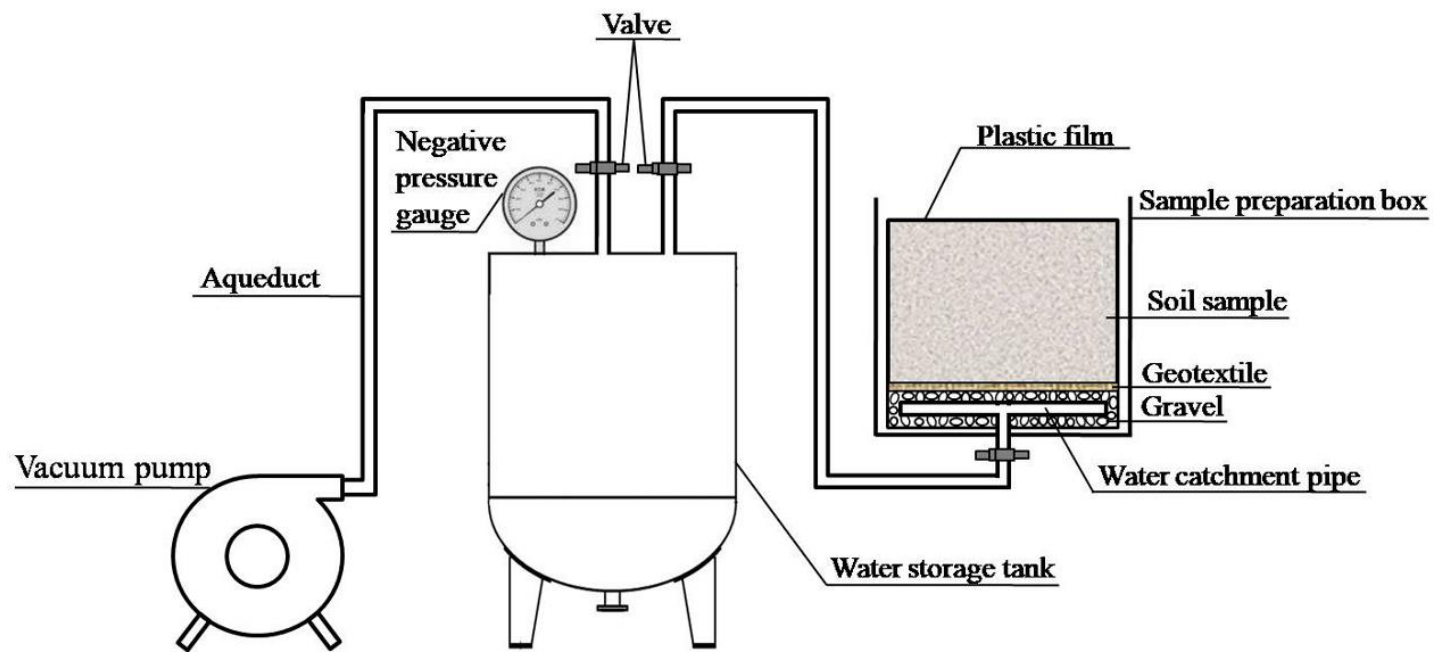

Figure 1. Equipment for preparing clay samples.

The fiber content is defined as follows:

$$
F C=\frac{m_{\mathrm{f}}}{m_{\mathrm{s}}}
$$

where $F C$ is the fiber content $(\%), m_{\mathrm{f}}$ is the mass of the fiber $(\mathrm{kg})$, and $m_{\mathrm{S}}$ is the mass of the dry soil $(\mathrm{kg})$. Specimens with different $F C(0.15 \%, 0.25 \%, 0.35 \%, 0.50 \%$, and $0.80 \%)$ were prepared.

Specimens with a diameter of $39.1 \mathrm{~mm}$ and a height of $80 \mathrm{~mm}$ were prepared by compaction in five layers in a specimen compactor, with the layer-layer interface smoothed. The prepared specimens were saturated using the air extraction method.

\subsection{Testing Method}

Triaxial shear tester with stress-strain control was used to conduct a series of consolidated undrained tests on specimens with different $F L$ and $F C$ at different cell pressures to investigate the shear strength characteristics of fiber-reinforced red clay. Table 3 shows the testing scheme. The specimens were prepared using the wet loading method. They were saturated, consolidated, and subjected to shearing. The strain control mode was used with a shear strain rate of $0.08 \mathrm{~mm} / \mathrm{min}$. A specimen was considered to fail when the principal stress difference peaked or, if no such a peak was observed, when the axial strain reached $15 \%$. 
Table 3. Test scheme.

\begin{tabular}{ccc}
\hline$\sigma_{3}(\mathbf{k P a})$ & $\boldsymbol{F L}(\mathbf{m m})$ & $\boldsymbol{F C}(\mathbf{\%})$ \\
\hline 100 & 0 & 0 \\
& 7 & $0.15,0.25,0.35,0.50,0.80$ \\
& 13 & $0.15,0.25,0.35,0.50,0.80$ \\
& 19 & $0.15,0.25,0.35,0.50,0.80$ \\
\hline 200 & 0 & 0 \\
& 7 & $0.15,0.25,0.35,0.50,0.80$ \\
& 13 & $0.15,0.25,0.35,0.50,0.80$ \\
& 19 & $0.15,0.25,0.35,0.50,0.80$ \\
\hline & 0 & 0 \\
& 7 & $0.15,0.25,0.35,0.50,0.80$ \\
& 13 & $0.15,0.25,0.35,0.50,0.80$ \\
& 19 & $0.15,0.25,0.35,0.50,0.80$ \\
\hline
\end{tabular}

\section{Results and Discussion}

\subsection{Shear Strength of Fiber-Reinforced Red Clay}

\subsubsection{Effect of Fiber Content on Strength}

Figure 2 shows the influence of $F C$ on the strength of the reinforced red clay with a cell pressure of $200 \mathrm{kPa}$. As shown in the figure, the specimens with different $F L$ exhibited basically consistent stress-strain curves, but the fiber-reinforced and plain red clay specimens exhibited completely different stress-strain curves. The axial strain of reinforced clay specimens increased as the deviatoric stress increased but exhibited no peak, whereas for the plain clay specimen, the axial strain first increased, then peaked and gradually decreased. This finding indicates that the fiber-reinforced red clay was characterized by strain hardening, which became more notable as FC increased. As shown in Figure 2c, if the ultimate strain is defined as $9 \%$, the peak strength of the plain red clay was $403 \mathrm{kPa}$; the specimens reinforced with $0.15 \%$ and $0.80 \% 19 \mathrm{~mm}$ fiber filaments had strengths of 671 and $1055 \mathrm{kPa}$, or improvements of $66.5 \%$ and $161.8 \%$, respectively. If the ultimate axial strain is defined as $15 \%$, the reinforced red clay specimens with the five different $F C$ had strengths of $755,832,915,1030$, and $1259 \mathrm{kPa}$, equal to 1.87 to 3.12 times the strength of the plain red clay. This result clearly indicates that the addition of fiber could improve the strength of clay specimens. These findings are in agreement with the results reported by Kumar et al. [10], where unconfined compressive strength tests were conducted.

\subsubsection{Effect of Fiber Length on Strength}

Figure 3 shows the effects of the reinforced specimens on strength at the different $F C$ levels, at the cell pressure of $200 \mathrm{kPa}$. For a given $F C$, the stiffness gradually increased as the $F L$ increased, and the strain-hardening characteristic became more notable, as shown by the increasing tangent modulus of the curves, indicating that the shear strength of reinforced red clay increases with increases in FL. Mirzababaei et al. [8] found a consistent conclusion by direct shear tests: the shear strength of fiber-reinforced soft soil increased as the $F L$ increased. For the red clay reinforced with randomly and uniformly distributed fiber filaments, there was a certain quantity of fiber filaments on the shear failure surface, and the two ends of the filaments were anchored on the two sides of the failure surface. When a relative dislocation between the two sides of the failure surface occurred, the fiber filaments were placed in tension. As shown in Table 2, the fiber had a large initial elasticity modulus and tensile strength (592 MPa). Therefore, the fiber provided a large tensile resistance at a small tensile deformation, thereby confining the extension of the failure surface and improving the shear strength. Because the tensile resistance provided by the fiber filaments was related to their length of anchorage on the two sides of the shear failure surface, the increase in $F L$ led to an increase in tensile resistance and shear strength until the tensile failure of the fiber. To verify the above-discussed inference, the parameters related to the consolidated undrained shear strength of specimens (Table 4) were analyzed. As can be 
seen in Table 4, at a certain $F L$, with the increase in $F C$, the $c$ clearly increases, but there is little variation in the $\varphi$ of the fiber-reinforced red clay. At a certain $F C$, with the increase in $F L$ the $c$ increases, but there is only a small variation in the $\varphi$. The results are consistent with those of Dong et al. [27] and Chen et al. [29].

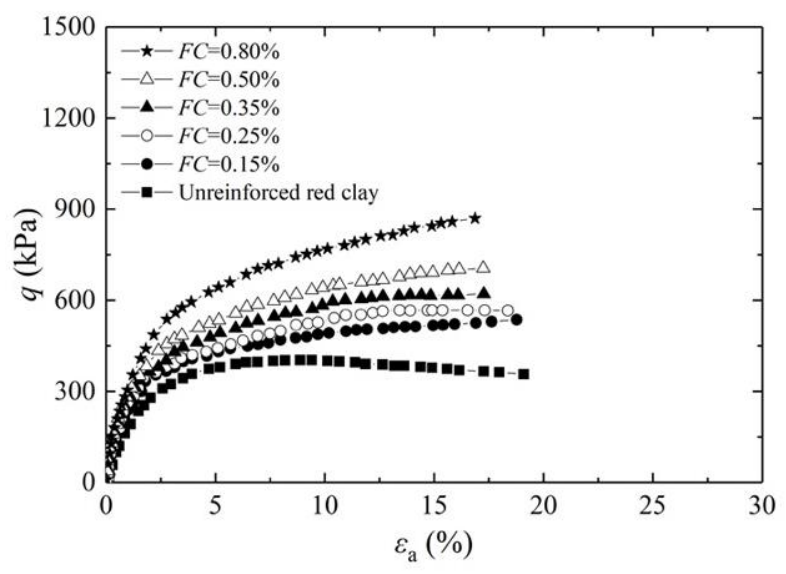

(a) $F L=7 \mathrm{~mm}$

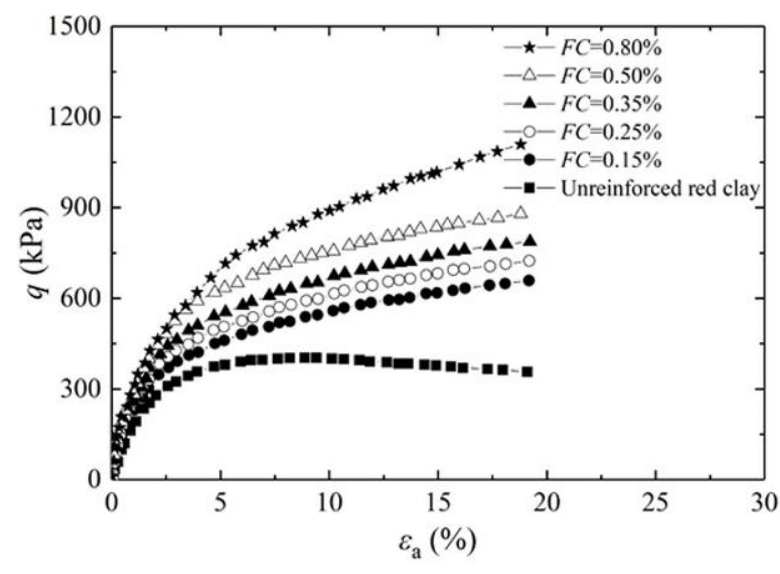

(b) $F L=13 \mathrm{~mm}$

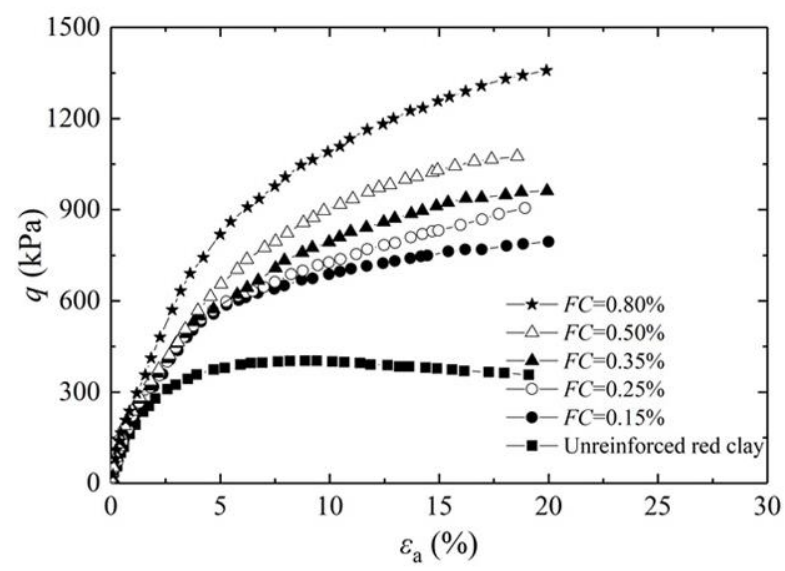

(c) $F L=19 \mathrm{~mm}$

Figure 2. Effect of fiber content on stress-strain $\left(\sigma_{3}=200 \mathrm{kPa}\right)$.

Table 4. Shear strength of fiber-reinforced red clay.

\begin{tabular}{cccc}
\hline $\begin{array}{c}\text { Fiber Length } \\
\boldsymbol{F L / m m}\end{array}$ & $\begin{array}{c}\text { Fiber Content } \\
\boldsymbol{F C} / \%\end{array}$ & $\begin{array}{c}\text { Cohesion } \\
\boldsymbol{c} / \mathbf{k P a}\end{array}$ & $\begin{array}{c}\text { Angle of Internal } \\
\text { Friction } \\
\left.\boldsymbol{\rho} / \mathbf{(}^{\circ}\right)\end{array}$ \\
\hline 0 & 0 & 93.25 & 14 \\
\hline 7 & 0.15 & 106.42 & 20 \\
& 0.25 & 125.16 & 20 \\
& 0.35 & 142.20 & 20 \\
& 0.50 & 163.58 & 20 \\
\hline 13 & 0.80 & 208.41 & 22 \\
\hline & 0.15 & 141.30 & 21 \\
& 0.25 & 160.85 & 21 \\
& 0.35 & 180.19 & 21 \\
& 0.50 & 211.54 & 21 \\
\hline
\end{tabular}


Table 4. Cont.

\begin{tabular}{cccc}
\hline $\begin{array}{c}\text { Fiber Length } \\
\boldsymbol{F L} / \mathbf{m m}\end{array}$ & $\begin{array}{c}\text { Fiber Content } \\
\boldsymbol{F C} / \%\end{array}$ & $\begin{array}{c}\text { Cohesion } \\
\boldsymbol{c} / \mathbf{k P a}\end{array}$ & $\begin{array}{c}\text { Angle of Internal } \\
\text { Friction } \\
\left.\boldsymbol{c} / \mathbf{(}^{\circ}\right)\end{array}$ \\
\hline 19 & 0.15 & 188.33 & 20 \\
& 0.25 & 211.19 & 21 \\
& 0.35 & 234.01 & 21 \\
& 0.50 & 270.95 & 22 \\
& 0.80 & 349.52 & 22 \\
\hline
\end{tabular}

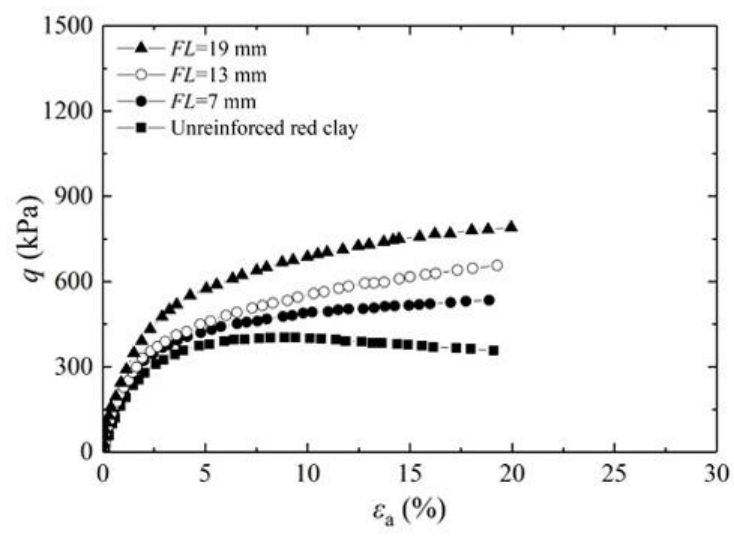

(a) $F C=0.15 \%$

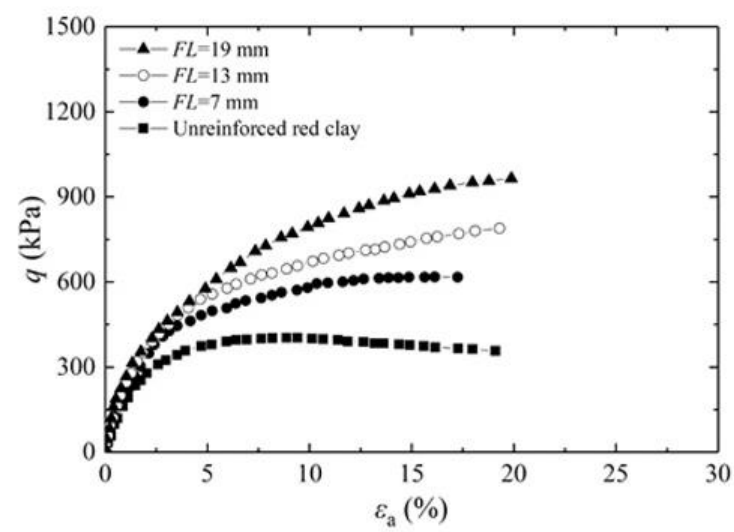

(c) $F C=0.35 \%$

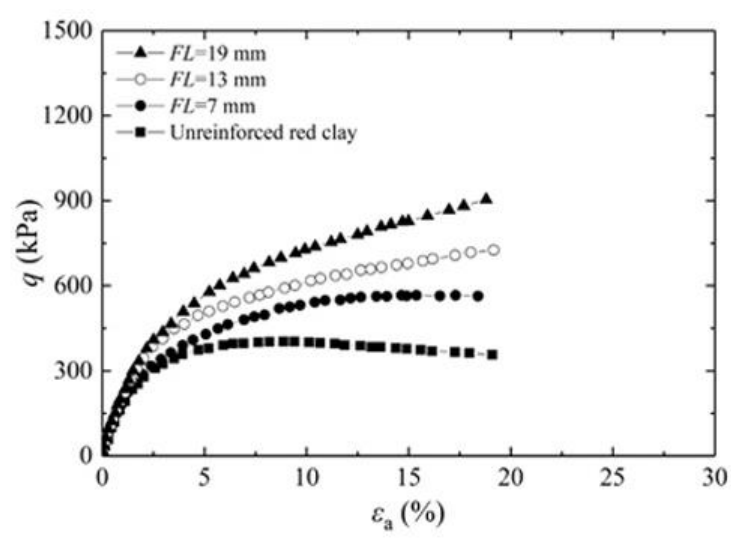

(b) $F C=0.25 \%$

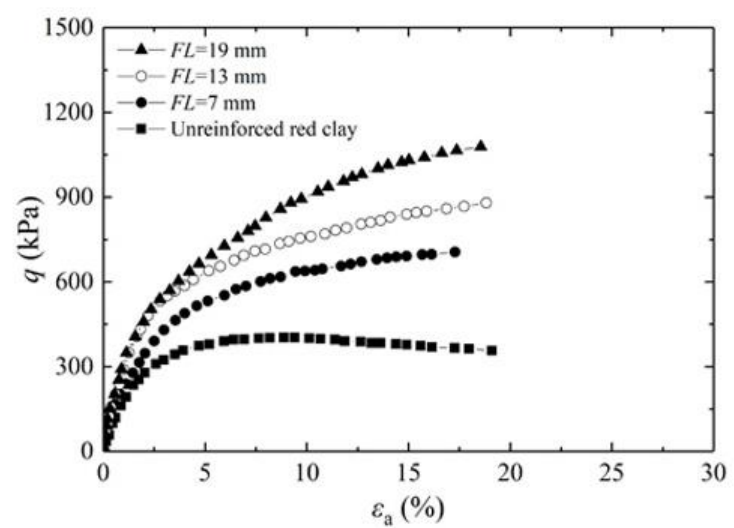

(d) $F C=0.50 \%$

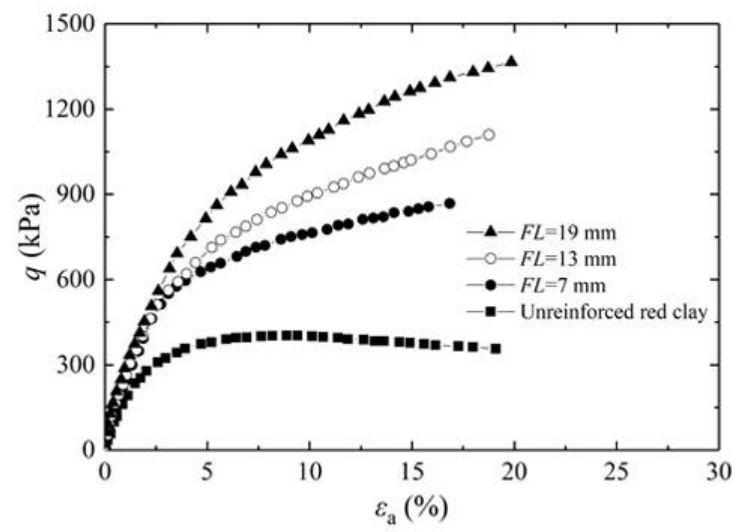

(e) $F C=0.80 \%$

Figure 3. Effect of fiber length on stress-strain $\left(\sigma_{3}=200 \mathrm{kPa}\right)$. 


\subsubsection{Effect of Cell Pressure on Strength}

Figure 4 exhibits the test results for the reinforced specimens with $F C$ of $0.25 \%$ and $0.50 \%$. As shown in the figure, the specimens with different $F L$ had similar stress-strain curves. The strength of the fiber-reinforced clay increased with cell pressure. Gao et al. [30] and Liu [31] studied the strength of basalt fiber-reinforced clay and silty clay, respectively, and reached consistent conclusions with this study. Anggraini et al. [22] investigated marine clay soil with nanomodified coir fiber and found that the treated soil had peak strength, and it increased with an increasing level of cell pressure. The red clay specimen reinforced with $0.50 \% 19 \mathrm{~mm}$ fiber filaments subjected to cell pressures of 100, 200, and $300 \mathrm{kPa}$ had strengths of 914,1030 , and $1143 \mathrm{kPa}$, respectively, at an axial strain of $15 \%$. For a given cell pressure, strength increased with the increase in $F C$. This positive relationship was more notable at large axial strains. The specimens mixed with $0.25 \%$ and $0.50 \% 19 \mathrm{~mm}$ fiber filaments had strengths of 949 and $1143 \mathrm{kPa}$, respectively, at a cell pressure of $300 \mathrm{kPa}$.

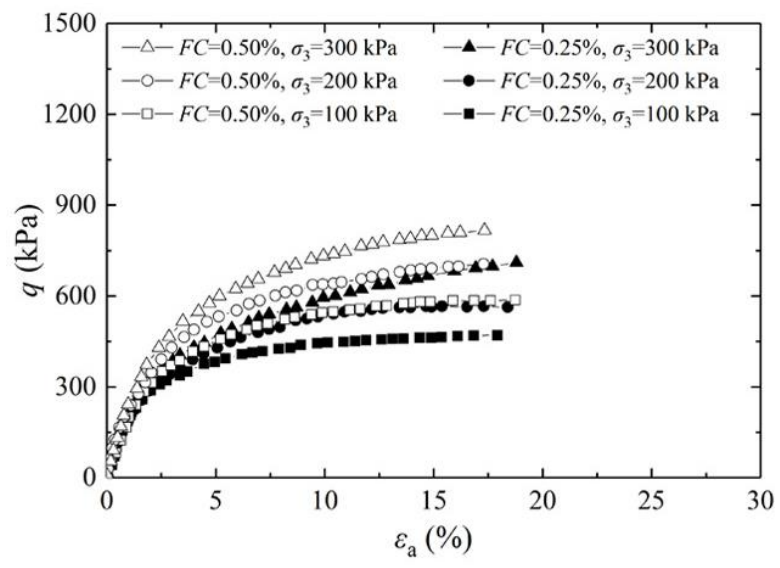

(a) $F L=7 \mathrm{~mm}$

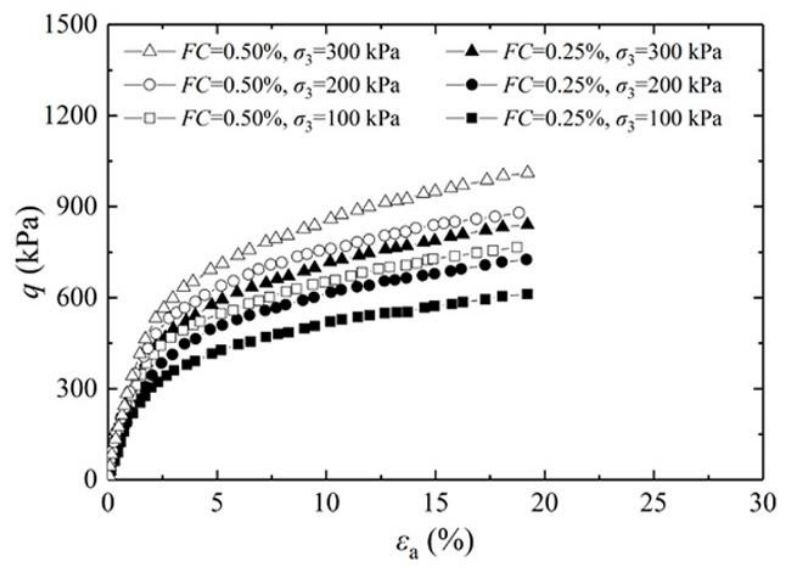

(b) $F L=13 \mathrm{~mm}$

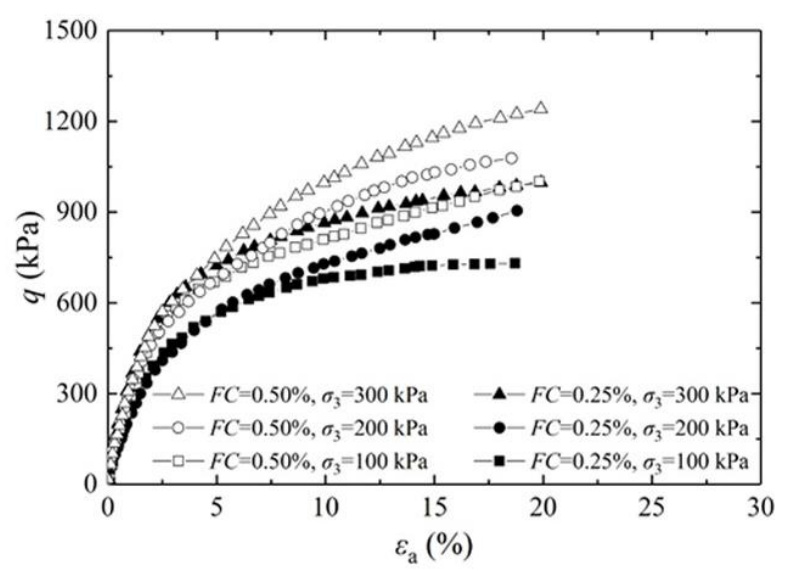

(c) $F L=19 \mathrm{~mm}$

Figure 4. Effect of cell pressure on stress-strain.

\subsection{Constitutive Model for Fiber-Reinforced Red Clay}

\subsubsection{Model Establishment}

Duncan and Chang [32] suggested that the stress-strain relationship of soils could be represented using the following hyperbolic model:

$$
\sigma_{1}-\sigma_{3}=\frac{\varepsilon_{1}}{a+b \varepsilon_{1}}
$$


where $\sigma_{1}$ is the axial stress, $\varepsilon_{1}$ is the axial strain, and $a$ and $b$ are testing parameters.

Equation (2) can be transformed as follows:

$$
\frac{\varepsilon_{1}}{\sigma_{1}-\sigma_{3}}=a+b \varepsilon_{1}
$$

The test results were plotted as $\varepsilon_{1} /\left(\sigma_{1}-\sigma_{3}\right)-\varepsilon_{1}$ curves. The intercept $a$ and slope $b$ of the fitted straight lines were obtained through regression. A single-factor analysis of the testing parameters showed that parameter $b$ was negatively related to $F C, F L$, and cell pressure. Thus, parameter $b$ can be defined as follows:

$$
b=\frac{a_{2}}{F L \cdot F C \cdot \sigma_{3}}
$$

Substituting Equation (4) into Equation (3) and arranging the terms gives the following equation:

$$
\frac{\varepsilon_{1}}{\sigma_{1}-\sigma_{3}}=a_{1}+\frac{a_{2}}{F L \cdot F C \cdot \sigma_{3}} \varepsilon_{1}
$$

where $a_{1}\left(a_{1}=a\right)$ and $a_{2}\left(a_{2}=b \cdot F L \cdot F C \cdot \sigma_{3}\right)$ are the two parameters of the model.

Thus, the two model parameters, $a_{1}$ and $a_{2}$, can be obtained by fitting test data.

\subsubsection{Fitting of Model Parameters}

Figure 5 shows the test results for the specimens with different $F L$ and $F C$ with a cell pressure of $200 \mathrm{kPa}$. The curves basically exhibit a linear relationship. At a certain $F L$, the curve slope decrease with the increase in $F C$. At a certain $F C$, the curve slope decreases with the increase in $F L$. The values of parameters $a, b, a_{1}$, and $a_{2}$ were obtained through regression of the test data, as shown in Table 5. The regression results at different cell pressures, $F L$, and $F C$ showed strong correlations, with the coefficients of determination $\left(R^{2}\right)$ being larger than 0.99 , confirming that the hyperbolic model is suitable for describing

\begin{tabular}{|c|c|c|c|c|c|c|c|c|c|}
\hline $\begin{array}{c}\sigma_{3} \\
(\mathbf{k P})\end{array}$ & $\begin{array}{c}F L \\
(\mathrm{~mm})\end{array}$ & $F C(\%)$ & $a$ & $b$ & $a_{1}$ & $a_{2}$ & $R^{2}$ & $a_{1}^{*}$ & $a_{2}{ }^{*}$ \\
\hline \multirow[t]{15}{*}{200} & 7 & 0.15 & 0.00269 & 0.00176 & 0.00269 & 0.00370 & 0.99966 & 0.00300 & 0.00370 \\
\hline & 7 & 0.25 & 0.00268 & 0.00161 & 0.00268 & 0.00564 & 0.99896 & & 0.00554 \\
\hline & 7 & 0.35 & 0.00251 & 0.00147 & 0.00251 & 0.00720 & 0.99909 & & 0.00739 \\
\hline & 7 & 0.50 & 0.00235 & 0.00132 & 0.00235 & 0.00924 & 0.99848 & & 0.00924 \\
\hline & 7 & 0.80 & 0.00222 & 0.00106 & 0.00222 & 0.01187 & 0.99817 & & 0.01109 \\
\hline & 13 & 0.15 & 0.00343 & 0.00141 & 0.00343 & 0.00550 & 0.99747 & & 0.00554 \\
\hline & 13 & 0.25 & 0.00305 & 0.00128 & 0.00305 & 0.00832 & 0.99734 & & 0.00832 \\
\hline & 13 & 0.35 & 0.00283 & 0.00118 & 0.00283 & 0.01074 & 0.99703 & & 0.01109 \\
\hline & 13 & 0.50 & 0.00254 & 0.00104 & 0.00254 & 0.01352 & 0.99819 & & 0.01386 \\
\hline & 13 & 0.80 & 0.00265 & 0.00082 & 0.00265 & 0.01706 & 0.99340 & & 0.01663 \\
\hline & 19 & 0.15 & 0.00385 & 0.00107 & 0.00385 & 0.00610 & 0.99940 & & 0.00628 \\
\hline & 19 & 0.25 & 0.00387 & 0.00095 & 0.00387 & 0.00903 & 0.99755 & & 0.00942 \\
\hline & 19 & 0.35 & 0.00376 & 0.00086 & 0.00376 & 0.01144 & 0.99748 & & 0.01257 \\
\hline & 19 & 0.50 & 0.00352 & 0.00075 & 0.00352 & 0.01425 & 0.99262 & & 0.01571 \\
\hline & 19 & 0.80 & 0.00305 & 0.00059 & 0.00305 & 0.01794 & 0.99771 & & 0.01885 \\
\hline
\end{tabular}
the stress-strain relationship of fiber-reinforced red clay.

Table 5. Model parameters under $200 \mathrm{kPa}$ cell pressure.

A statistical analysis of the model parameters showed the following patterns: (1) For a given cell pressure, parameter $a_{1}$ varies in a small range as $F L$ and content vary. Thus, the mean value of parameter $a_{1}$ is used as the approximate value of $a_{1}^{*}$. (2) For a given cell pressure and $F L$, the value of parameter $a_{2}$ increases with $F C$. Thus, the value of $a_{2}$ at $F C=0.15 \%$ is used as the basic value of $a_{2}$. The values of $a_{2}{ }^{*}$ at the other five content levels are calculated as follows: $a_{2}{ }^{*}(F C=0.25 \%)=1.5 a_{2}{ }^{*}(F C=0.15 \%) ; a_{2}{ }^{*}(F C=0.35 \%)=2.0 a_{2}{ }^{*}$ $(F C=0.15 \%) ; a_{2}{ }^{*}(F C=0.50 \%)=2.5 a_{2}{ }^{*}(F C=0.15 \%) ; a_{2}{ }^{*}(F C=0.80 \%)=3.0 a_{2}{ }^{*}(F C=0.15 \%)$. 
(3) For a given cell pressure and $F C$, the value of parameter $a_{2}$ increases with $F L$. Thus, the value of $a_{2}$ at $F L=7 \mathrm{~mm}$ is used as the basic value. The values of $a_{2}{ }^{*}$ at the other $F L$ are calculated as follows: $a_{2}{ }^{*}(F L=13 \mathrm{~mm})=1.5 a_{2}{ }^{*}(F L=7 \mathrm{~mm}) ; a_{2}{ }^{*}(F L=19 \mathrm{~mm})=1.7 a_{2}{ }^{*}$ $(F L=7 \mathrm{~mm})$.

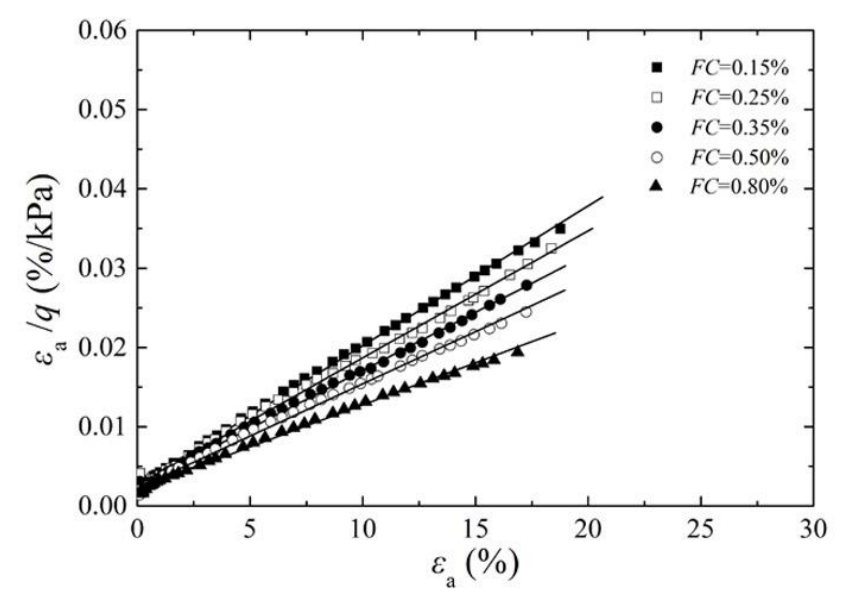

(a) $F L=7 \mathrm{~mm}$

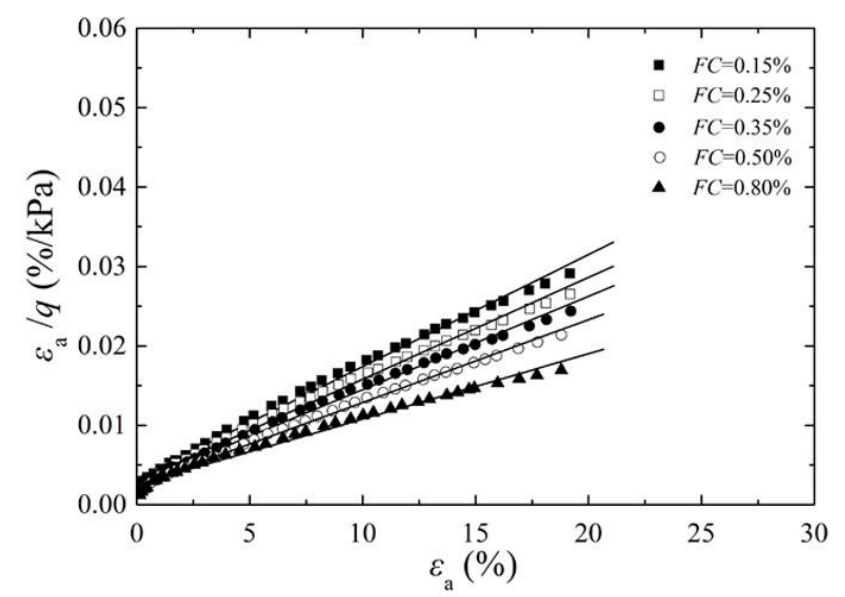

(b) $F L=13 \mathrm{~mm}$

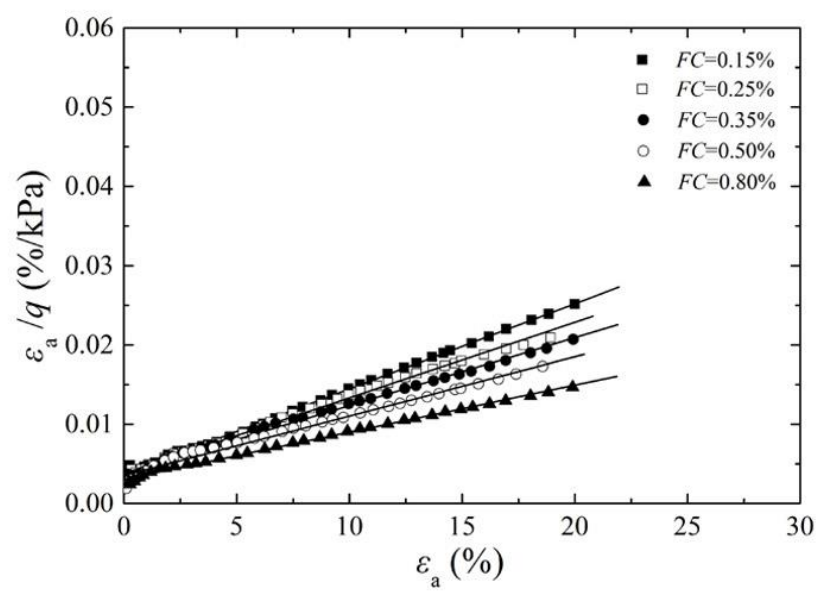

(c) $F L=19 \mathrm{~mm}$

Figure 5. Fitting of the measured results $\left(\sigma_{3}=200 \mathrm{kPa}\right)$.

Parameters $a_{1}^{*}$ and $a_{2}^{*}$ are estimated using the above-mentioned method. Table 5 shows the results. Thus, for fiber-reinforced red clay subjected to a given cell pressure, the parametric values of the constitutive model at the basic conditions ( $F L=7 \mathrm{~mm}, F C=0.15 \%)$ can be obtained by conducting a test under these basic conditions and performing a regression analysis on the test data; the parametric values for other conditions can be derived using the above-discussed relationships, thereby significantly reducing the number of tests that would otherwise be necessary to characterize the stress-strain relationship under different conditions.

\subsubsection{Model Validation}

To prove the validity of the model, the test results under cell pressures of 100 and $300 \mathrm{kPa}$ were calculated according to the above-mentioned method. The calculation results of the parameters are shown in Table 6. The estimated parametric values in Tables 5 and 6 were substituted into Equation (5) to obtain the deviatoric stress of the fiber-reinforced red clay using the known axial strain. The comparison of the measured and predicted results is shown in Figure 6. The model results agree well with the test results with different cell 
pressures, $F L$ and $F C$, with a maximum error of less than $10 \%$, thus proving that the model can appropriately express the stress-strain relationship of fiber-reinforced red clay.

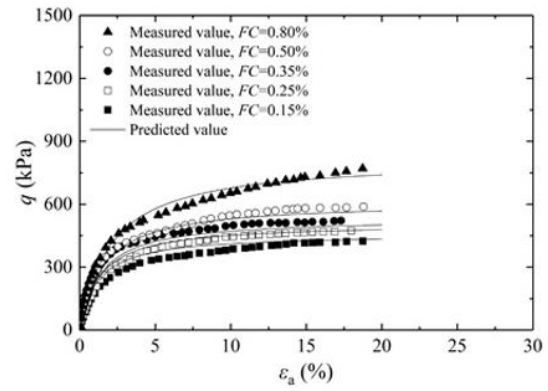

(a) $\sigma_{3}=100 \mathrm{kPa}, F L=7 \mathrm{~mm}$

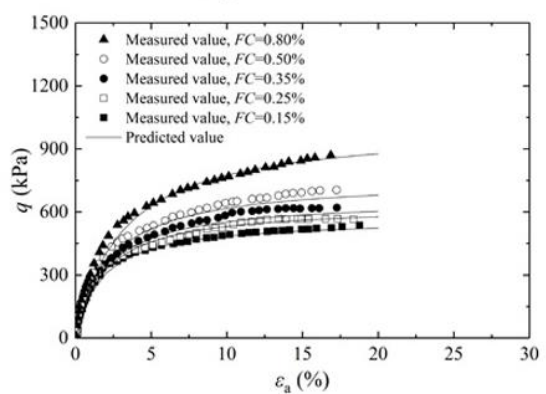

(d) $\sigma_{3}=200 \mathrm{kPa}, F L=7 \mathrm{~mm}$

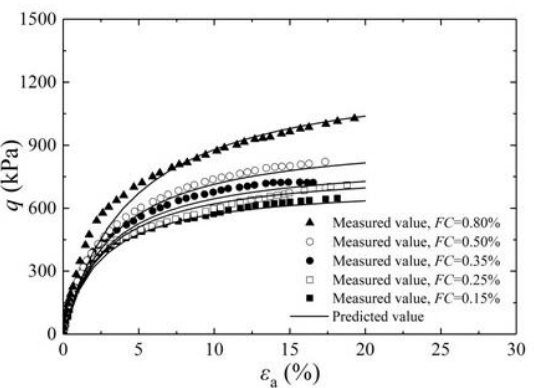

(g) $\sigma_{3}=300 \mathrm{kPa}, F L=7 \mathrm{~mm}$

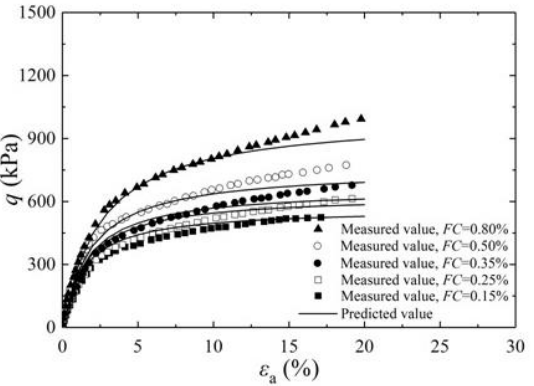

(b) $\sigma_{3}=100 \mathrm{kPa}, F L=13 \mathrm{~mm}$

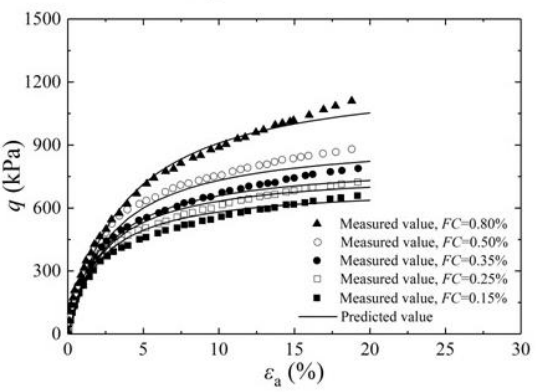

(e) $\sigma_{3}=200 \mathrm{kPa}, F L=13 \mathrm{~mm}$

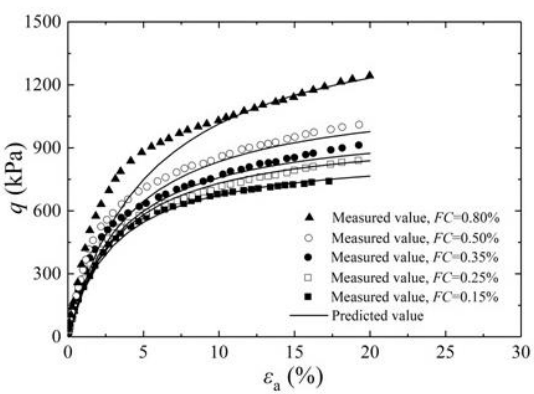

(h) $\sigma_{3}=300 \mathrm{kPa}, F L=13 \mathrm{~mm}$

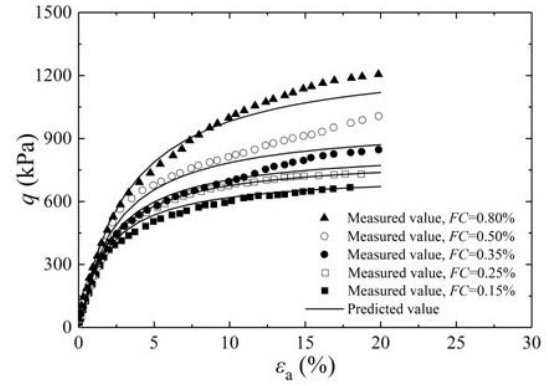

(c) $\sigma_{3}=100 \mathrm{kPa}, F L=19 \mathrm{~mm}$

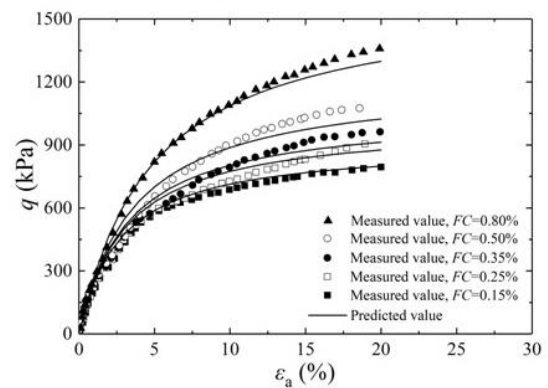

(f) $\sigma_{3}=200 \mathrm{kPa}, F L=19 \mathrm{~mm}$

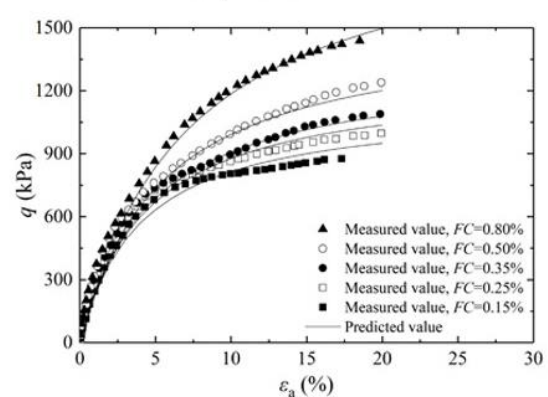

(i) $\sigma_{3}=300 \mathrm{kPa}, F L=19 \mathrm{~mm}$

Figure 6. Comparison of measured and predicted results.

Table 6. Model parameters under 100 and $300 \mathrm{kPa}$ cell pressure.

\begin{tabular}{|c|c|c|c|c|c|c|c|c|c|}
\hline $\begin{array}{c}\sigma_{3} \\
(\mathbf{k P})\end{array}$ & $\begin{array}{c}F L \\
(\mathrm{~mm})\end{array}$ & $F C(\%)$ & $a$ & $b$ & $a_{1}$ & $a_{2}$ & $R^{2}$ & $a_{1}^{*}$ & $a_{2}{ }^{*}$ \\
\hline \multirow[t]{15}{*}{100} & 7 & 0.15 & 0.00304 & 0.00218 & 0.00304 & 0.00229 & 0.99941 & 0.00250 & 0.00229 \\
\hline & 7 & 0.25 & 0.00242 & 0.00194 & 0.00242 & 0.00340 & 0.99989 & & 0.00344 \\
\hline & 7 & 0.35 & 0.00152 & 0.00182 & 0.00152 & 0.00446 & 0.99982 & & 0.00458 \\
\hline & 7 & 0.50 & 0.00171 & 0.00160 & 0.00171 & 0.00560 & 0.99901 & & 0.00573 \\
\hline & 7 & 0.80 & 0.00184 & 0.00124 & 0.00184 & 0.00694 & 0.99696 & & 0.00687 \\
\hline & 13 & 0.15 & 0.00318 & 0.00171 & 0.00318 & 0.00334 & 0.99947 & & 0.00344 \\
\hline & 13 & 0.25 & 0.00328 & 0.00148 & 0.00328 & 0.00481 & 0.99847 & & 0.00515 \\
\hline & 13 & 0.35 & 0.00296 & 0.00134 & 0.00296 & 0.00610 & 0.99853 & & 0.00687 \\
\hline & 13 & 0.50 & 0.00212 & 0.00121 & 0.00212 & 0.00787 & 0.99795 & & 0.00859 \\
\hline & 13 & 0.80 & 0.00205 & 0.00094 & 0.00205 & 0.00978 & 0.99713 & & 0.01031 \\
\hline & 19 & 0.15 & 0.00303 & 0.00134 & 0.00303 & 0.00382 & 0.99979 & & 0.00389 \\
\hline & 19 & 0.25 & 0.00252 & 0.00120 & 0.00252 & 0.00570 & 0.99988 & & 0.00584 \\
\hline & 19 & 0.35 & 0.00294 & 0.00105 & 0.00294 & 0.00698 & 0.99787 & & 0.00779 \\
\hline & 19 & 0.50 & 0.00257 & 0.00090 & 0.00257 & 0.00855 & 0.99734 & & 0.00973 \\
\hline & 19 & 0.80 & 0.00234 & 0.00071 & 0.00234 & 0.01079 & 0.99629 & & 0.01168 \\
\hline
\end{tabular}


Table 6. Cont.

\begin{tabular}{cccccccccc}
\hline $\begin{array}{c}\sigma_{\mathbf{3}} \\
(\mathbf{k P})\end{array}$ & $\begin{array}{c}\boldsymbol{F L} \\
(\mathbf{m m})\end{array}$ & $\boldsymbol{F C} \mathbf{( \% )}$ & $\boldsymbol{a}$ & $\boldsymbol{b}$ & $\boldsymbol{a}_{\mathbf{1}}$ & $\boldsymbol{a}_{\mathbf{2}}$ & $\boldsymbol{R}^{\mathbf{2}}$ & $\boldsymbol{a}_{\mathbf{1}}{ }^{*}$ & $\boldsymbol{a}_{\mathbf{2}}{ }^{*}$ \\
\hline 300 & 7 & 0.15 & 0.00361 & 0.00140 & 0.00361 & 0.00441 & 0.99916 & 0.00350 & 0.00441 \\
& 7 & 0.25 & 0.00348 & 0.00131 & 0.00348 & 0.00688 & 0.99663 & & 0.00662 \\
& 7 & 0.35 & 0.00339 & 0.00122 & 0.00339 & 0.00897 & 0.99945 & & 0.00882 \\
& 7 & 0.50 & 0.00325 & 0.00108 & 0.00325 & 0.01134 & 0.99890 & & 0.01103 \\
& 7 & 0.80 & 0.00314 & 0.00090 & 0.00314 & 0.01512 & 0.99801 & & 0.01323 \\
& 13 & 0.15 & 0.00383 & 0.00117 & 0.00383 & 0.00684 & 0.99991 & & 0.00662 \\
& 13 & 0.25 & 0.00367 & 0.00107 & 0.00367 & 0.01043 & 0.99877 & & 0.00992 \\
& 13 & 0.35 & 0.00343 & 0.00099 & 0.00343 & 0.01351 & 0.99836 & & 0.01323 \\
& 13 & 0.50 & 0.00336 & 0.00090 & 0.00336 & 0.01755 & 0.99865 & & 0.01654 \\
& 13 & 0.80 & 0.00327 & 0.00074 & 0.00327 & 0.02309 & 0.99845 & & 0.01985 \\
& 19 & 0.15 & 0.00369 & 0.00098 & 0.00369 & 0.00838 & 0.99913 & & 0.00750 \\
& 19 & 0.25 & 0.00364 & 0.00088 & 0.00364 & 0.01254 & 0.99966 & & 0.01125 \\
& 19 & 0.35 & 0.00363 & 0.00081 & 0.00363 & 0.01616 & 0.99800 & & 0.01499 \\
& 19 & 0.50 & 0.00361 & 0.00070 & 0.00361 & 0.01995 & 0.99621 & & 0.01874 \\
& 19 & 0.80 & 0.00353 & 0.00058 & 0.00353 & 0.02645 & 0.99498 & & 0.02249 \\
\hline
\end{tabular}

\section{Conclusions}

Triaxial tests were conducted to study the mechanical properties of fiber-reinforced red clay and to investigate the effects of $F C, F L$, and cell pressure on its shear strength. Through fitting the experimental data, a hyperbolic constitutive model that considers the effects of FC, FL, and cell pressure was established. The major conclusions are summarized as follows:

(1) The stress-strain curve of the fiber-reinforced red clay exhibited a typical strainhardening property, which became more notable as FC and FL increased. The shear strength of the fiber-reinforced red clay significantly increased as $F C, F L$, and cell pressure increased.

(2) The fiber could provide tensile resistance at a small deformation, thereby confining the extension of the failure surface and improving the shear strength. With an increases in $F C$ and $F L$, the cohesion $c$ of the fiber-reinforced red clay increased significantly, whereas the internal friction angle $\varphi$ varied only slightly.

(3) When considering the impact of cell pressure, $F L$, and $F C$, the results of the hyperbolic constitutive model coincide with test results well, confirming that the model can appropriately express the stress-strain relationship of the fiber-reinforced red clay.

In this paper, the shear properties of fiber-reinforced red clay were investigated only under static loading. In future studies, the mechanical properties of fiber-reinforced red clay under dynamic loading, the stress path, and the reinforcement mechanism will be the focus points.

Author Contributions: Conceptualization, J.L. and X.L.; methodology, G.L.; validation, J.L., G.L. and J.Z.; formal analysis, J.L.; data curation, J.Z.; writing-original draft preparation, J.L. and X.L.; writing-review and editing, J.L. and G.L. All authors have read and agreed to the published version of the manuscript.

Funding: This research was funded by the National Natural Science Foundation of China (41877225); the Fundamental Research Funds for the Central Universities, CHD (300102261719); the Natural Science Basic Research Program of Shaanxi Province (2021JM-535); and the Special Fund for Scientific Research by Xijing University(XJ18T01).

Institutional Review Board Statement: Not applicable.

Informed Consent Statement: Not applicable.

Data Availability Statement: Not applicable.

Conflicts of Interest: The authors declare no conflict of interest. 


\section{References}

1. Wang, H.; Yang, G.Q.; Wang, Z.J.; Liu, W.C. Static structural behavior of geogrid reinforced soil retaining walls with a deformation buffer zone. Geotext Geomembr. 2020, 48, 374-379. [CrossRef]

2. Zhang, R.; Long, M.X.; Lan, T.; Zheng, J.L.; Geoff, C. Stability analysis method of geogrid reinforced expansive soil slopes and its engineering application. J. Cent. South Univ. 2020, 27, 1965-1980. [CrossRef]

3. Lee, S.L.; Mannan, M.A.; Ibrahim, W.H.W. Shear strength evaluation of composite pavement with geotextile as reinforcement at the interface. Geotext Geomembr. 2020, 48, 230-235. [CrossRef]

4. Cicek, E. Experimental and theoretical investigation for highways incorporating geotextile design methodology. Road Mater. Pavement. 2018, 21, 965-984. [CrossRef]

5. Li, L.; Fall, M. Shear behavior of marine clay-geomembrane interface under freeze-thaw cycles. J. Environ. Geotech. 2018, 172, 103006.

6. Zeng, J.; Peng, X.X.; Ruan, B.; Li, X.S.; Zeng, Y. Experimental study on unconfined compressive strength of polypropylene fiber reinforced red clay. J. Railw. Sci. Eng. 2015, 12, 545-550.

7. Gao, L.; Zhou, Q.Y.; Yu, X.J.; Wu, K.X.; Mahfouz, A.H. Experimental study on the unconfined compressive strength of carbon fiber reinforced clay soil. Mar. Georesour. Geotec. 2017, 35, 143-148. [CrossRef]

8. Mirzababaei, M.; Arulrajah, A.; Haque, A.; Nimbalkar, S.; Mohajerani, A. Effect of fiber reinforcement on shear strength and void ratio of soft clay. Geosynth. Int. 2018, 25, 471-480. [CrossRef]

9. Ozkul, Z.H.; Baykal, G. Shear strength of clay with rubber fiber inclusions. Geosynth. Int. 2006, 13, 173-180. [CrossRef]

10. Kumar, A.; Walia, B.S.; Mohan, J. Compressive strength of fiber reinforced highly compressible clay. Constr. Build Mater. 2006, 20, 1063-1068. [CrossRef]

11. Gao, C.H.; Du, G.Y.; Guo, Q.; Xia, H. Dynamic and static splitting-tensile properties of basalt fiber-reinforced cemented clay under freeze-thaw cycles. J. Mater. Civil. Eng. 2020, 32, 0003350. [CrossRef]

12. Li, Q.; Chen, J.H.; Hu, H.X. The tensile and swelling behavior of cement-stabilized marine clay reinforced with short waste fibers Mar. Georesour. Geotec. 2019, 37, 1236-1246. [CrossRef]

13. Zhang, X.D.; Russell, A.R. Assessing liquefaction resistance of fiber-reinforced sand using a new pore pressure ratio. J. Geotech. Geoenviron. 2020, 146, 04019125. [CrossRef]

14. Sargin, S.; Erken, A. Cyclic behavior and liquefaction resistance of polypropylene fiber-reinforced sands. Bull. Int. Inst. Seismol. Earthq. Eng. 2018, 52, 38-49.

15. Sahu, R.; Ramaiah, J.; Ayothiraman, R.; Gunturi, R. Dynamic properties of human hair fiber-reinforced Yamuna sand. J. Test Eval. 2019, 48, 20180133. [CrossRef]

16. Rafalko, S.D.; Brandon, T.L.; Filz, G.M.; Mitchell, J.K. Fiber reinforcement for rapid stabilization of soft clay soils. Transp. Res. Rec. J. Transp. Res. Board 2007, 2026, 21-29. [CrossRef]

17. Boz, A.; Sezer, A. Influence of fiber type and content on freeze-thaw resistance of fiber reinforced lime stabilized clay. Cold Reg. Sci. Technol. 2018, 151, 359-366. [CrossRef]

18. Tomar, A.; Sharma, T.; Singh, S. Strength properties and durability of clay soil treated with mixture of nano silica and polypropylene fiber. Mater. Today Proc. 2020, 26, 3449-3457. [CrossRef]

19. Estabragh, A.R.; Namdar, P.; Javadi, A.A. Behavior of cement-stabilized clay reinforced with nylon fiber. Geosynth. Int. 2012, 19, 85-92. [CrossRef]

20. Gao, L.; Hu, G.H.; Xu, N.; Fu, J.Y.; Xiang, C.; Yang, C. Experimental study on unconfined compressive strength of basalt fiber reinforced clay soil. Adv. Mater. Sci. Eng. 2015, 2015, 561293. [CrossRef]

21. Basson, M.S.; Ayothiraman, R. Effect of human hair fiber reinforcement on shrinkage cracking potential of expensive clay. $B$ Eng. Geol. Environ. 2020, 79, 2159-2168. [CrossRef]

22. Anggraini, V.; Asadi, A.; Farzadnia, N.; Jahangirian, H.; Huat, B.B.K. Reinforcement benefits of nanomodified coir fiber in lime-treated marine clay. J. Mater. Civil.Eng. 2016, 28, 06016005. [CrossRef]

23. Olgun, M. Effects of polypropylene fiber inclusion on the strength and volume change characteristics of cement-fly ash stabilized clay soil. Geosynth. Int. 2013, 20, 263-275. [CrossRef]

24. Kravchenko, E.; Liu, J.K.; Krainiukov, A.; Chang, D. Dynamic behavior of clay modified with polypropylene fiber under freeze-thaw cycles. Transp. Geotech. 2019, 21, 100282. [CrossRef]

25. Xue, Q.; Lu, H.J.; Li, Z.Z.; Liu, L. Cracking, water permeability and deformation of compacted clay liners improved by straw fiber. Eng. Geol. 2014, 178, 82-90.

26. Jiang, Z.L.; Wang, C.G.; Xiao, W.; Ruan, B. Laboratory investigation and numerical simulation of unconfined compressive strength of glass fiber reinforced soil. J. Railw. Sci. Eng. 2020, 17, 1404-1410.

27. Dong, J.; Chen, J.; Wu, Z.H.; Yang, H.; Chen, T.X. Experimental study on the shear strength and deformation characteristics of lignin-fiber red clay. J. Geomech. 2019, 25, 421-427.

28. Wan, Y.Y.; Peng, X.X. Experimental study on compression properties of glass fiber and lime reinforced red clay. Highw. Eng. 2017, 42, 281-284.

29. Chen, J.Y.; Liu, Z.K.; Chen, Y.G.; Xi, D.N. Orthogonal test and multivariate nonlinear regression analyses of strength of the fiber red clay. Hydrogeol. Eng. Geol. 2020, 47, 117-124. 
30. Gao, L.; Hu, G.H.; Chen, Y.H.; Hu, Y.J.; Gong, Y.H. Triaxial tests clay reinforced by basalt fiber. Chin. J. Geotech. Eng. 2017, 39, 198-203.

31. Liu, T. Experimental investigation on the static and dynamic characteristics of silty clay reinforced with basalt fiber. J. Railw. Sci. Eng. 2020, 17, 1734-1742.

32. Duncan, J.M.; Chang, C.Y. Nonlinear analysis of stress and strain in soils. J. Soil Mech. Found. Div. ASCE 1970, 96, 1629-1653. [CrossRef] 